\title{
Factors associated with adherence to a web-based alcohol intervention among college students
}

\section{Fatores associados à adesão a uma intervenção}

via web sobre o uso de álcool

entre universitários

\author{
Marcella Ferreira GONÇALVES ${ }^{1}$ ID 0000-0002-4319-4875 \\ André BEDENDO ${ }^{1,2}$ iD 0000-0001-9554-6564 \\ André Luiz Monezi ANDRADE ${ }^{3}$ 0000-0003-0111-8935 \\ Ana Regina NOTO1 ${ }^{1}$ (D) 0000-0003-2622-6668
}

\begin{abstract}
This study aimed to evaluate the association between student characteristics and recruitment strategies in the adherence of college students to a web-based alcohol intervention. Participants were 46,329 Brazilian students aged from 18 to 30 , who consumed alcohol during the past three months. Three recruitment strategies were implemented: open invitations, and personally-addressed invitations with or without non-monetary incentives. We evaluated the educational, sociodemographic, motivational, and alcohol consumption effects on adherence using logistic regression models. Women $(\mathrm{aOR}=1.09[1.04 ; 1.14])$, students with higher income (aOR $=1.32[1.21 ; 1.45])$, and more motivated students $(\mathrm{aOR}=1.04[1.03 ; 1.05])$ were more adherent to the intervention, as well as those reporting binge drinking $(\mathrm{aOR}=1.26[1.19 ; 1.33])$ and alcohol hazardous use $(\mathrm{aOR}=1.11[1.05 ; 1.18])$. The use of incentives was the main
\end{abstract}

1 Universidade Federal de São Paulo, Núcleo de Pesquisa sobre Saúde e Uso de Substâncias, Departamento de Psicobiologia. São Paulo, SP, Brasil.

2 University of York, Mental Health and Addiction Research Group, Department of Health Sciences. Seebohm Rowntree Building, Heslington, York, YO10 5DD, United Kingdom. Correspondence to: A. BEDENDO. E-mail: <andre.bedendo@unifesp.br>.

3 Pontifícia Universidade Católica de Campinas (PUC-Campinas), Centro de Ciências da Vida, Programa de Pós-Graduação em Psicologia. Campinas, SP, Brasil.

Article based on the master's dissertation of M.F. GONÇALVES, entitled "Adesão a uma intervenção via web para o uso de álcool entre universitários: influência do perfil dos participantes e das estratégias de recrutamento”. Universidade Federal de São Paulo, 2019.

Support: Fundação de Amparo à Pesquisa do Estado de São Paulo (Grants 2013/20341-7, 2015/19472-5, 2017/13831-9, and 2018/12729-9).

How to cite this article

Gonçalves, M. F., Bedendo, A., Andrade, A. L. M., \& Noto, A. R. (2021). Factors associated with adherence to a web-based alcohol intervention among college students. Estudos de Psicologia (Campinas), 38, e190134. https://doi.org/10.1590/1982-0275202138e190134 
factor associated with adherence $(a O R=3.69$ [2.46; 5.55]). Our results may help the development of future web-based interventions related to alcohol use.

Keywords: Alcoholic beverages; Incentive; Internet; Patient compliance; Patient portals; Student health.

\section{Resumo}

O presente estudo teve como objetivo avaliar a influência do perfil dos estudantes e das estratégias de recrutamento na adesão de universitários a uma intervenção via web sobre o uso de álcool. Participaram da pesquisa 46.329 estudantes brasileiros com idade entre 18 e 30 anos e relatando consumo de álcool nos últimos três meses. Utilizaram-se três estratégias de recrutamento: convite aberto e convite pessoalmente dirigido com e sem incentivo não monetário. Avaliouse o efeito de características educacionais, sociodemográficas, motivacionais e de uso de álcool sobre a adesão por meio de modelos de regressão logística. Mulheres $(a O R=1,09[1,04 ; 1,14])$, estudantes com maior renda (aOR = 1,32 $[1,21 ; 1,45])$ e mais motivados $(a O R=1,04[1,03 ; 1,05])$ foram mais aderentes, bem como universitários que relataram binge (aOR $=1,26[1,19 ; 1,33])$ e uso de risco (aOR $=1,11[1,05 ; 1,18])$. O emprego de incentivos foi o principal fator associado à adesão (aOR = 3,69 [2,46; 5,55]). Os resultados podem auxiliar no desenvolvimento de futuras intervenções sobre o uso de álcool via internet.

Palavras-chave: Bebidas alcoólicas; Incentivo; Internet; Cooperação do paciente; Portais do paciente; Saúde do estudante.

Alcohol is the most consumed psychoactive substance worldwide (World Health Organization [WHO], 2018), with college students reporting a higher frequency of use and more negative consequences than their non-college peers (Schulenberg et al., 2018). In the United States, 76\% of all college students reported alcohol use during the last year and 62\% during the past month; of those, 33\% were also binge drinkers - that is, consumed five or more units in a single occasion (Schulenberg et al., 2018). In Brazil, a survey conducted in all 27 capitals indicated that $86 \%$ of college students reported lifetime alcohol use, and $25 \%$ of them reported binge drinking during the last 30 days (Andrade, Duarte, \& Oliveira, 2010). Binge drinking is particularly prevalent among college students and it is associated with short and long-term physical, social, and academic problems, such as traffic accidents, violent acts, health issues, and diminished academic productivity among this population (Andrade et al., 2010; Bedendo, Andrade, Opaleye, \& Noto, 2017). Due to the higher levels of alcohol use and few available programs aiming to reduce alcohol use among college students (Andrade et al., 2010), some authors stress an urgent need to implement preventive approaches and counseling targeting this population (Silva \& Tucci, 2015).

Technological and socioeconomic advances during the last years enabled an increasing part of the Brazilian population to have internet access. The last survey on the use of technology in Brazil showed that around 54\% of Brazilian homes had access to the internet in 2016 (Comitê Gestor da Internet no Brasil [CGI], 2017). This scenario increased the interest in using electronic health (e-Health) interventions, whereby health services are offered via electronic devices (WHO, 2015). The availability of e-Health strategies is especially relevant among college students and nearly $73 \%$ of this population seek health-related content online (Escoffery et al., 2005). Moreover, e-Health interventions are available 24 hours a day, favor anonymity, do not require previous scheduling, and show reduced maintenance costs (Andrade et al., 2016; Schaub et al., 2018; Sundstrom, Blankers, \& Khadjesari, 2017; van der Mispel, Poppe, Crombez, Verloigne, \& Bourdeaudhuij, 2017).

Although such interventions have the potential to reach a large number of individuals, studies highlighted that its actual use might be limited due to the high dropout rates (Laguilles, Williams, \& Saunders 2011; Schulz et al., 2013). High dropout rates are common in e-Health interventions and could jeopardize

their effects due to the low exposure of participants to the intervention content (Brouwer et al., 2011), consequently reducing the internal and external validity of the results (Geraghty, Wood, \& Hyland, 2010).

2 For instance, fully-adherent participants might represent a group of more "hardcore" users who are more 
motivated (Eysenbach, 2005), and predicting the level and risk of dropout can enable personalized goals which would help to re-engage participants (Pedersen, Mansourvar, Sorts, \& Schmidt, 2019). However, a systematic review highlighted that knowledge on predictors of adherence to online interventions is yet preliminary and that there is a need for more studies in this regard (Beatty \& Binnion, 2016).

Heavy alcohol users and with high levels of nicotine dependence are less prone to remain in web-based alcohol interventions and the retention of participants with a less risky pattern of consumption tends to bias the results of the intervention and their interpretation (Geraghty, Torres, Leykin, Pérez-Stable, \& Muñoz, 2013; Radtke, Ostergaard, Cooke, \& Scholz, 2017). However, it is still unclear how much of the effect on dropout rates in alcohol web-based interventions are related to individual alcohol use or a higher interest of students in receiving incentives for participating in the research (Radtke et al., 2017).

Incentives (financial, gift supply, emission of certificates, etc.) are frequently offered in order to improve adherence rates in web-based researches and are a traditional manner of motivating participants (Bedendo, Andrade, \& Noto, 2018; Laguilles et al., 2011). However, such practices impair the validity of web-based researches since they may attract participants who are less committed with the intervention (Göritz, 2006). Therefore, the use of incentives must be considered in order to comprehend the real effectiveness of web-based alcohol interventions (Bedendo \& Noto, 2016). A recent study suggested a strong selection bias in web-based alcohol interventions for college students, where students were more likely to participate when they received incentives, and highlighted the need for additional work examining the effects of incentives (Neighbors et al., 2018).

The present study aimed to evaluate the association between student characteristics and recruitment strategies in the adherence of college students to a web-based alcohol intervention. We hypothesized that the adherence would be higher among students receiving incentives and participants with lower levels of alcohol use.

\section{Method}

\section{Study design}

The present study is a secondary analysis of a pragmatic randomized controlled trial that evaluated the effectiveness of a web-based alcohol brief intervention (Personalized Normative Feedback) among Brazilian college students. The intervention is named Pesquisa Universitária sobre Bebidas (Undergraduate Alcohol Research) and it had its effectiveness and components evaluated. Participants received either the full intervention or two of its dismantled components. Intervention components were: drinking characteristics, normative comparisons, practical costs of alcohol use (money spent on alcohol and its monetary equivalents in goods, calories consumed, weight gained, and time to burn calories), alcohol-related consequences and likely future consequences, low-risk drinking limits, and strategies to reduce risk drinking. The intervention was proven effective in reducing typical drinking among Brazilian college students. For more details, please refer to (Bedendo, Ferri, Andrade, \& Noto, 2019a; Bedendo et al., 2019b).

\section{Participants}

The sample was composed of 46,329 college students from all Brazilian regions. The inclusion criteria were: age between 18 and 30 years old, alcohol use during the past three months, and being a student enrolled in a higher education institution. Individuals not meeting the inclusion criteria were able to complete the questionnaires, but did not receive the intervention.

Since the dataset derives from a study that aimed to evaluate the effectiveness of an intervention and its more effective components, participants were randomized into one of four arms: (1) Control; (2) 
Complete Intervention; (3) Normative Intervention only; and (4) Consequences Intervention only. This aspect was considered in the statistical analyses and the regression models were adjusted for the type of intervention received.

Participants were recruited in three ways: (i) Open invitation without incentives: via the institutional website and Facebook page of the Centro de Integração Empresa-Escola (CIEE, Education-Business Integration Centre); (ii) Addressed invitations without incentives: Four hundred thousand invitations were sent via e-mail, for online addresses gathered from a database of college students that were already registered in the CIEE database; and (iii) Addressed invitations with an incentive: 903 invitations were sent via e-mail, a procedure mediated by a professor in a private university in the city of São Paulo. All participants were informed that academic credits (10 hours) would be granted if they accomplished all intervention stages. These credits could be used as part of the complementary activities required by the university as part of the undergraduate curriculum.

Regardless of the form of recruitment, prior registration on the CIEE platform was required to participate in the research, through which information was cross-checked to confirm that the participant was properly registered as a college student. In all recruitment strategies, students were invited to access a website to "Evaluate their consumption of alcoholic beverages in less than five minutes".

\section{Procedures}

The data was collected between October 2015 and September 2016. Follow-ups with participants were performed after 1, 3, and 6 months and participants received e-mail reminders (a maximum of five reminders in each follow-up, in alternate days) informing about the need to return to the website. Participants who logged in to the CIEE platform in a date close to that of the follow-up also received a pop-up reminder.

\section{Instruments}

All the participants answered the following instruments, considering the past three months.

Sociodemographic questionnaire: Sex, age, region, and household income in minimum wages.

Educational characteristics: Course (humanities, biological, or exact sciences); term or year of the course in which the student is currently enrolled; and type of institution (public or private).

Alcohol use: The Alcohol Use Disorders Identification Test (AUDIT) was used - the scale has ten items and is validated both for college students and the Brazilian population. The analysis considered the total AUDIT score (ranging from 0 to 40) and the risk patterns according to the original scale: Low-Risk (0-7), Hazardous Use (8-15), Harmful Use (16-19), and Possible Dependence (20-40). The number of typical drinks was assessed using the second question of the AUDIT questionnaire.

To evaluate additional consequences associated with alcohol use, we used the following questions: (i) drinking and driving behavior (driving or taking a ride with someone who drank); (ii) academic issues; (iii) problems with relatives or acquaintances; (iv) nausea or vomiting; (v) fights; (vi) impulsive behaviors; and (vii) unprotected sex. The questions were based on the Rutgers Alcohol Problem Index (RAPI), except for the question regarding impulsive behaviors. We opted not to use the full RAPI questionnaire as the original version of the scale was too long (23 questions) and increasing the number of questions would hinder adherence (Poppe et al., 2017), and due to the overlap of other questions assessed through the AUDIT questionnaire. We generated a final score using a simple sum of the number of consequences (ranging from 0 to 8 ).

We also included questions about the maximum number of drinks consumed in a single occasion 4 during the previous year and the time when they were consumed, weight and height of the participant (to 
estimate the blood alcohol content), financial expenditure on alcoholic beverages per event, age at first use, and age at first drunkenness episode. Finally, we considered a question on the use of a fictitious drug aiming to increase the accuracy of responses "Have you ever consumed alcohol with Medavane?". Participants who answered yes to this question were excluded from the final sample.

Motivational aspects: We asked participants, "How motivated are you to know more about your current alcohol consumption?" and used a visual analog scale ranging from 0 (totally unmotivated) to 10 (totally motivated).

Adherence: Students who returned to at least one of the three follow-ups were considered adherent. This variable was dichotomous: 0 = non-adherent; 1 = adherent.

This study was approved by the Ethics Committee of Universidade Federal de São Paulo (Federal University of São Paulo, Unifesp, CEP: 429.170 and 1.462.856) and Universidade Anhembi Morumbi (Anhembi Morumbi University, CEP: 1.039.264). All participants expressed their consent on the first page of the website before obtaining access to the research content.

\section{Data Analysis}

The data was analyzed using STATA version 14 and considered a minimum significance level of $5 \%$. We used exploratory analyses in the form of frequencies, measures of central tendency, and graphic representations to observe the distribution of variables. Comparisons of participant characteristics were performed using chi-squared tests $\left(\chi^{2}\right)$ and Analysis of Variance, according to the variable type.

Logistic regression models were employed to assess the effect of recruitment strategies, gender, socioeconomic level, and alcohol consumption characteristics (independent variables) on the adherence of participants (dependent variable). These analyses considered a sample size of 43,610 students (2,719 participants who did not provide information about the household income were excluded).

From a total of 903 invitations, 281 students (31.1\%) accessed the website and received the incentives. Thus, the analyzes of the effects of the different recruitment strategies on adherence used a subsample of participants $(N=802)$. We drew a paired subsample of participants not receiving the incentives in order to ensure appropriate statistical inferences about the groups. All participants who received the incentives were enrolled in a private Institution in the state of São Paulo. Therefore, only the students from that private institution were included in the drawing. The sampling was paired by sex and used the STATA command sample. The command allowed to draw a random sample of $5.0 \%$ of the participants recruited via addressed invitations without incentives (e-mail) and $2.0 \%$ of those recruited via open invitations without incentives (CIEE website and Facebook page). These proportions aimed to maintain the parity of participants in each category of interest (the type of recruitment and sex) and the suitability to perform the statistical analyses. The final sample of 802 was composed of 269 participants recruited via open invitations without incentives, 267 via addressed invitations without incentives, and 266 with incentives.

\section{Results}

\section{Sample characteristics}

Table 1 shows sociodemographic, educational, and recruitment characteristics of the total sample $(N=46,332)$, adherent, and non-adherent groups, whereas characteristics related to alcohol consumption are shown in Table 2. A little more than half of the university students were female (50.5\%), most students were from a public university $(82.4 \%)$, were majoring in the humanities area $(53.1 \%)$, reported a family income between 1-3 salaries (55.2\%) and were recruited by open invitation without incentives (73.8\%). Most university students were classified as low-risk use by AUDIT (71.9\%) and reported binge drinking (71.1\%). 
Table 1

Sociodemographic, educational, and recruitment characteristics of participants $(N=46,329)$

\begin{tabular}{|c|c|c|c|c|c|c|c|}
\hline \multirow{3}{*}{$\begin{array}{l}\text { Sociodemographic, educational, and } \\
\text { recruitment variables }\end{array}$} & \multirow{2}{*}{\multicolumn{2}{|c|}{$\begin{array}{c}\text { Non-adherent } \\
n=38,099\end{array}$}} & \multirow{2}{*}{\multicolumn{2}{|c|}{$\begin{array}{l}\text { Adherent } \\
n=8,230\end{array}$}} & \multirow{2}{*}{\multicolumn{2}{|c|}{$\begin{array}{c}\text { Total } \\
N=46,329\end{array}$}} & \multirow{3}{*}{$p$} \\
\hline & & & & & & & \\
\hline & $n$ & $\%$ & $n$ & $\%$ & $n$ & $\%$ & \\
\hline \multicolumn{8}{|l|}{ Sex } \\
\hline Female & 19,105 & 50.1 & 4,275 & 51.9 & 23,380 & 50.5 & \multirow[t]{2}{*}{ *** } \\
\hline Male & 18,994 & 49.9 & 3,955 & 48.1 & 22,949 & 49.5 & \\
\hline \multicolumn{8}{|l|}{ Household income (R\$) } \\
\hline Unknown & 2,252 & 5.9 & 467 & 5.7 & 2,719 & 5.9 & \multirow[t]{5}{*}{$* * *$} \\
\hline 1 to 3 minimum wages & 21,344 & 56.0 & 4,218 & 51.2 & 25,562 & 55.1 & \\
\hline 3 to 5 minimum wages & 7,020 & 18.4 & 1,646 & 20.0 & 8,666 & 18.7 & \\
\hline 5 a 10 minimum wages & 4,850 & 12.7 & 1,209 & 14.7 & 6,059 & 13.1 & \\
\hline 10 or more minimum wages & 2,633 & 7.0 & 690 & 8.4 & 3,323 & 7.2 & \\
\hline \multicolumn{8}{|l|}{ Region } \\
\hline North and Northeast & 9,920 & 26.0 & 1,900 & 23.1 & 11,820 & 25.5 & \multirow[t]{3}{*}{$* * *$} \\
\hline South and Southeast & 21,064 & 55.3 & 4,731 & 57.5 & 25,795 & 55.7 & \\
\hline Midwest & 7,115 & 18.7 & 1,599 & 19.4 & 8,714 & 18.8 & \\
\hline \multicolumn{8}{|l|}{ College } \\
\hline Private & 31,600 & 82.9 & 6,561 & 79.7 & 38,161 & 82.4 & \multirow[t]{2}{*}{ *** } \\
\hline Public & 6,499 & 17.1 & 1,669 & 20.3 & 8,168 & 17.6 & \\
\hline \multicolumn{8}{|l|}{ Course } \\
\hline Humanities & 20,105 & 52.8 & 4,480 & 54.4 & 24,585 & 53.1 & \multirow[t]{3}{*}{ *** } \\
\hline Biological Sciences & 14,704 & 38.6 & 3,006 & 36.5 & 17,710 & 38.2 & \\
\hline Exact Sciences & 3,290 & 8.6 & 744 & 9.1 & 4,034 & 8.7 & \\
\hline \multicolumn{8}{|l|}{ Type of recruitment } \\
\hline Open invitation without incentives & 28,306 & 74.8 & 5,680 & 69.2 & 33,986 & 73.8 & \multirow[t]{3}{*}{ *** } \\
\hline Addressed invitation without incentives & 9,400 & 24.8 & 2,391 & 29.1 & 11,791 & 25.6 & \\
\hline \multirow[t]{2}{*}{ Incentives } & 144 & 0.4 & 137 & 1.7 & 281 & 0.6 & \\
\hline & $M$ & $S D$ & $M$ & $S D$ & $M$ & $S D$ & \\
\hline Age & 21.9 & 3.0 & 21.8 & 3.0 & 21.9 & 3.0 & **** \\
\hline College year & 2.9 & 1.5 & 2.8 & 1.5 & 2.9 & 1.5 & $* * *$ \\
\hline Motivation & 5.7 & 3.6 & 6.2 & 3.4 & 5.8 & 3.6 & $* * *$ \\
\hline
\end{tabular}

Note: ${ }^{* * *} p<0.001$.

p: Significance level; R\$: Real Brazilian Currency; M: Mean; SD: Standard Deviation.

Table 2

Alcohol consumption characteristics of participants $(N=46,329)$

\begin{tabular}{|c|c|c|c|c|c|c|c|}
\hline \multirow{3}{*}{ Alcohol use variables } & \multirow{2}{*}{\multicolumn{2}{|c|}{$\begin{array}{c}\text { Non-adherent } \\
n=38,099\end{array}$}} & \multirow{2}{*}{\multicolumn{2}{|c|}{$\begin{array}{l}\text { Adherent } \\
n=8,230\end{array}$}} & \multirow{2}{*}{\multicolumn{2}{|c|}{$\begin{array}{c}\text { Total } \\
N=46,329\end{array}$}} & \multirow{3}{*}{$p$} \\
\hline & & & & & & & \\
\hline & $n$ & $\%$ & $n$ & $\%$ & $n$ & $\%$ & \\
\hline \multicolumn{8}{|l|}{ Risk Zone - AUDIT } \\
\hline $\begin{array}{l}\text { Low risk use } \\
\text { Hazardous use } \\
\text { Harmful use } \\
\text { Possible dependence } \\
\text { Typical drinks }\end{array}$ & $\begin{array}{c}27,503 \\
8,435 \\
1,233 \\
928\end{array}$ & $\begin{array}{r}72.2 \\
22.1 \\
3.2 \\
2.5\end{array}$ & $\begin{array}{c}5,808 \\
1,984 \\
262 \\
176\end{array}$ & $\begin{array}{r}70.6 \\
24.1 \\
3.2 \\
2.1\end{array}$ & $\begin{array}{c}33,311 \\
10,419 \\
1,495 \\
1,104\end{array}$ & $\begin{array}{c}71.9 \\
22.5 \\
3.2 \\
2.4\end{array}$ & $* * *$ \\
\hline $\begin{array}{l}1 \text { or } 2 \text { drinks } \\
3 \text { or } 4 \text { drinks } \\
5 \text { or } 6 \text { drinks } \\
7,8 \text { or } 9 \text { drinks } \\
10 \text { or more drinks } \\
\text { Lifetime binge drinking }\end{array}$ & $\begin{array}{r}13,349 \\
11,521 \\
7,469 \\
3,430 \\
2,330\end{array}$ & $\begin{array}{r}35.1 \\
30.2 \\
19.6 \\
9.0 \\
6.1\end{array}$ & $\begin{array}{l}2,643 \\
2,638 \\
1,646 \\
799 \\
504\end{array}$ & $\begin{array}{r}32.1 \\
32.1 \\
20.0 \\
9.7 \\
6.1\end{array}$ & $\begin{array}{l}15,992 \\
14,159 \\
9,115 \\
4,229 \\
2,330\end{array}$ & $\begin{array}{c}34.5 \\
30.6 \\
19.7 \\
9.1 \\
6.1\end{array}$ & $* * *$ \\
\hline \multirow[t]{2}{*}{ No } & $\begin{array}{l}26,775 \\
11,324 \\
\end{array}$ & $\begin{array}{l}70.3 \\
29.7\end{array}$ & $\begin{array}{l}6,156 \\
2,074 \\
\end{array}$ & $\begin{array}{l}74.8 \\
25.2\end{array}$ & $\begin{array}{l}32,931 \\
13,398 \\
\end{array}$ & $\begin{array}{l}71.1 \\
28.9 \\
\end{array}$ & *** \\
\hline & $M$ & $S D$ & $M$ & $S D$ & $M$ & $S D$ & \\
\hline AUDIT Score & 5.83 & 5.0 & 6.04 & 5.0 & 5.86 & 5.0 & $* * *$ \\
\hline Maximum drinks & 6.82 & 6.4 & 6.95 & 6.6 & 6.84 & 6.3 & 0.09 \\
\hline Number of consequences & 2.18 & 1.9 & 2.14 & 1.8 & 2.17 & 1.8 & $* * *$ \\
\hline
\end{tabular}

Note: ${ }^{* * *} p<0.001$.

6 AUDIT: Alcohol Use Disorders Identification Test; p: Significance level; M: Mean; SD: Standard Deviation. 
Table 3 shows sociodemographic, educational, and alcohol consumption characteristics of the subsample $(N=802)$, as segregated by recruitment strategies. Most university students were female (81.3), reported family incomes between $1-3$ salaries (49.3\%), were majoring in the humanities $(62.2 \%)$, were classified as low-risk use by AUDIT (73.7\%), and reported binge drinking (66.5\%).

\section{Adherence of participants}

Out of 46,329 participants, $82.2 \%$ did not return to the website, $14.8 \%$ returned in one follow-up, $3.5 \%$ in two, and $3.0 \%$ returned in all follow-ups. Table 4 shows data obtained from adjusted logistic regression models that predicted the students' adherence to the intervention. Analyzes showed that women, students from public institutions, and who reported more motivation were more adherent to the intervention. Participants from the South and Southeast and from the Midwest were also more adherent, as well as students with higher family incomes. On the other hand, students who have been enrolled in the university for more extended periods were less adherent. We found no statistically significant difference concerning the age of the participants.

Table 3

Sociodemographic, educational, and alcohol consumption characteristics of participants $(N=802)$

\begin{tabular}{|c|c|c|c|c|c|c|c|c|c|}
\hline \multirow{3}{*}{$\begin{array}{l}\text { Sociodemographic, educational, and } \\
\text { alcohol use variables }\end{array}$} & \multirow{2}{*}{\multicolumn{2}{|c|}{$\begin{array}{c}\text { Open invitations } \\
n=269 \\
\end{array}$}} & \multirow{2}{*}{\multicolumn{2}{|c|}{$\begin{array}{c}\text { Addressed invitations } \\
n=267 \\
\end{array}$}} & \multirow{2}{*}{\multicolumn{2}{|c|}{$\begin{array}{c}\text { Incentive } \\
n=266 \\
\end{array}$}} & \multirow{2}{*}{\multicolumn{2}{|c|}{$\begin{array}{c}\text { Total } \\
N=802\end{array}$}} & \multirow{3}{*}{$p$} \\
\hline & & & & & & & & & \\
\hline & $n$ & $\%$ & $n$ & $\%$ & $n$ & $\%$ & $n$ & $\%$ & \\
\hline \multicolumn{10}{|l|}{ Sex } \\
\hline $\begin{array}{l}\text { Female } \\
\text { Male }\end{array}$ & $\begin{array}{c}217 \\
52\end{array}$ & $\begin{array}{l}80.7 \\
19.3\end{array}$ & $\begin{array}{c}218 \\
49\end{array}$ & $\begin{array}{l}81.6 \\
18.4\end{array}$ & $\begin{array}{c}217 \\
49\end{array}$ & $\begin{array}{l}81.6 \\
18.4\end{array}$ & $\begin{array}{l}652 \\
150\end{array}$ & $\begin{array}{l}81.3 \\
18.7\end{array}$ & 0.94 \\
\hline \multicolumn{10}{|l|}{ Household income (R\$) } \\
\hline 1 to 3 minimum wages & 162 & 60.2 & 165 & 61.8 & 68 & 25.6 & 395 & 49.3 & \multirow[t]{4}{*}{$* * *$} \\
\hline 3 to 5 minimum wages & 63 & 23.4 & 45 & 16.9 & 78 & 29.3 & 186 & 23.2 & \\
\hline 5 a 10 minimum wages & 30 & 11.2 & 42 & 15.7 & 79 & 29.7 & 151 & 18.8 & \\
\hline 10 or more minimum wages & 14 & 5.2 & 15 & 5.6 & 41 & 15.4 & 70 & 8.7 & \\
\hline \multicolumn{10}{|l|}{ Course } \\
\hline Humanities & 159 & 59.1 & 138 & 51.7 & 202 & 75.9 & 499 & 62.2 & \multirow[t]{3}{*}{$* * *$} \\
\hline Biological Sciences & 31 & 11.5 & 34 & 12.7 & 63 & 23.7 & 128 & 16.0 & \\
\hline Exact Sciences & 79 & 29.4 & 95 & 35.6 & 1 & 0.4 & 4175 & 21.8 & \\
\hline \multicolumn{10}{|l|}{ AUDIT Risk Zone } \\
\hline Low risk use & 222 & 82.5 & 183 & 68.5 & 186 & 69.9 & 591 & 73.7 & \multirow[t]{4}{*}{ *** } \\
\hline Hazardous use & 42 & 15.6 & 60 & 22.5 & 72 & 27.1 & 174 & 21.7 & \\
\hline Harmful use & 4 & 1.5 & 15 & 5.6 & 3 & 1.1 & 22 & 2.7 & \\
\hline Possible dependence & 1 & 0.4 & 9 & 3.4 & 5 & 1.9 & 15 & 1.9 & \\
\hline \multicolumn{10}{|l|}{ Typical drinks } \\
\hline 1 or 2 drinks & 128 & 47.6 & 100 & 37.4 & 86 & 32.3 & 314 & 39.2 & \multirow[t]{5}{*}{$* * *$} \\
\hline 3 or 4 drinks & 75 & 27.9 & 87 & 32.6 & 95 & 35.7 & 257 & 32.0 & \\
\hline 5 or 6 drinks & 51 & 18.9 & 45 & 16.9 & 54 & 20.3 & 150 & 18.7 & \\
\hline 7,8 or 9 drinks & 12 & 4.5 & 26 & 9.7 & 20 & 7.5 & 58 & 7.2 & \\
\hline 10 or more drinks & 3 & 1.1 & 9 & 3.4 & 11 & 4.2 & 23 & 2.9 & \\
\hline \multicolumn{10}{|l|}{ Lifetime binge drinking } \\
\hline Yes & 167 & 62.1 & 161 & 60.3 & 205 & 77.1 & 533 & 66.5 & \multirow[t]{2}{*}{ *** } \\
\hline \multirow[t]{2}{*}{ No } & 102 & 37.9 & 106 & 39.7 & 61 & 22.9 & 269 & 33.5 & \\
\hline & $M$ & $S D$ & $M$ & $S D$ & $M$ & $S D$ & $M$ & $S D$ & \\
\hline Age & 21.9 & 3.1 & 21.3 & 3.0 & 21.4 & 3.0 & 21.6 & 3.0 & 0.70 \\
\hline College year & 2.5 & 1.2 & 2.3 & 1.2 & 2.6 & 1.3 & 2.5 & 1.3 & 0.22 \\
\hline Motivation & 6.00 & 3.8 & 6.5 & 3.5 & 6.0 & 3.4 & 6.2 & 3.6 & 0.24 \\
\hline AUDIT Score & 4.30 & 3.9 & 6.13 & 5.5 & 6.05 & 4.5 & 5.49 & 4.7 & $* * *$ \\
\hline Maximum drinks & 4.68 & 4.2 & 6.13 & 5.7 & 6.27 & 5.3 & 5.69 & 5.2 & $* * *$ \\
\hline Number of consequences & 1.75 & 1.6 & 2.27 & 1.9 & 2.08 & 1.7 & 2.03 & 1.76 & $* * *$ \\
\hline
\end{tabular}

Note: ${ }^{* * *} p<0.001$.

AUDIT: Alcohol Use Disorders Identification Test; p: Significance level; R\$: Real Brazilian Currency; M: Mean; SD: Standard Deviation. 
Table 4

Adjusted logistic regression models predicting adherence (reference $=$ non-adherent)

\begin{tabular}{|c|c|c|c|}
\hline Variable & Category & $\mathrm{aOR}$ & $95 \% \mathrm{Cl}$ \\
\hline \multicolumn{4}{|c|}{ Sociodemographic $^{1}(n=43,610)$} \\
\hline Sex & Male & ref & \\
\hline & Female & 1.09 & [1.04 -1.14] \\
\hline Age & 1 to 3 minimum wages & $\begin{array}{l}0.99 \\
\text { ref }\end{array}$ & {$[0.98-1.00]$} \\
\hline Household income & $\begin{array}{l}3 \text { to } 5 \text { minimum wages } \\
5 \text { a } 10 \text { minimum wages } \\
10 \text { or more minimum wages }\end{array}$ & $\begin{array}{l}1.17 \\
1.25 \\
1.32\end{array}$ & $\begin{array}{l}{[1.1-1.25]} \\
{[1.16-1.34]} \\
{[1.21-1.45]}\end{array}$ \\
\hline Region & $\begin{array}{l}\text { North and Northeast } \\
\text { South and Southeast } \\
\text { Midwest }\end{array}$ & $\begin{array}{l}\text { ref } \\
1.16 \\
1.13\end{array}$ & $\begin{array}{l}{[1.09-1.23]} \\
{[1.05-1.22]}\end{array}$ \\
\hline University & $\begin{array}{l}\text { Private } \\
\text { Public }\end{array}$ & $\begin{array}{l}\text { ref } \\
1.25\end{array}$ & {$[1.18-1.36]$} \\
\hline $\begin{array}{l}\text { Academic year } \\
\text { Motivation }\end{array}$ & - & $\begin{array}{l}0.95 \\
1.04\end{array}$ & $\begin{array}{l}{[0.94-0.97]} \\
{[1.03-1.05]}\end{array}$ \\
\hline \multicolumn{4}{|c|}{ Alcohol consumption $^{1}(n=43,610)$} \\
\hline AUDIT Score & -- & 1.01 & {$[1.01-1.02]$} \\
\hline AUDIT (Risk zone) & $\begin{array}{l}\text { Low-risk } \\
\text { Hazardous use } \\
\text { Harmful use } \\
\text { Possible dependence }\end{array}$ & $\begin{array}{l}\text { ref } \\
1.11 \\
1.01 \\
0.89\end{array}$ & $\begin{array}{l}{[1.05-1.18]} \\
{[0.88-1.17]} \\
{[0.75-1.05]}\end{array}$ \\
\hline Typical drinks & $\begin{array}{l}1 \text { or } 2 \text { drinks } \\
3 \text { or } 4 \text { drinks } \\
5 \text { or } 6 \text { drinks } \\
7,8 \text { or } 9 \text { drinks } \\
10 \text { or more drinks }\end{array}$ & $\begin{array}{l}\text { ref } \\
1.13 \\
1.12 \\
1.19 \\
1.14\end{array}$ & $\begin{array}{l}{[1.06-1.20]} \\
{[1.04-1.20]} \\
{[1.09-1.30]} \\
{[1.02-1.27]}\end{array}$ \\
\hline Maximum drinks & -- & 1.01 & {$[1.01-1.02]$} \\
\hline Number of Consequences & -- & 0.99 & [0.98-1.00] \\
\hline Lifetime binge drinking & Yes & 1.26 & [1.19-1.33] \\
\hline \multicolumn{4}{|c|}{ Recruitment strategy $^{2}(N=802)$} \\
\hline Recruitment & $\begin{array}{l}\text { Open invitation without incentives } \\
\text { Addressed invitation (no incentives) } \\
\text { Incentive (academic credits) }\end{array}$ & $\begin{array}{c}\text { ref } \\
1.15 \\
3.69\end{array}$ & $\begin{array}{l}{[0.76-1.77]} \\
{[2.46-5.55]}\end{array}$ \\
\hline
\end{tabular}

Note: ${ }^{1}$ models adjusted for sex, age, income, region, and intervention received; ${ }^{2}$ models adjusted for sex, age, income and intervention received. aOR: Adjusted Odds Ratio; AUDIT: Alcohol Use Disorders Identification Test; Cl: Confidence Interval; ref: reference.

Regarding the participants' alcohol use, higher AUDIT scores, larger maximum number of drinks consumed in a single occasion, and binge drinking were associated with increased odds of adherence. The same was true for participants with hazardous use when compared to low-risk users. Reporting a higher number of typical drinks consumed was also related to higher adherence. The number of negative alcohol-related consequences was not significantly related to adherence.

\section{Effect of recruitment strategy on adherence}

In the subsample employed to evaluate the effect of recruitment strategies ( $N=802), 11.5 \%$ of participants returned in all follow-ups, $13.0 \%$ in only one, $5.0 \%$ in two follow-ups, and $70.5 \%$ did not return. Compared to the students who did not receive incentives and were recruited by open invitations, those who received academic credits were 3.69 times more adherent $(a O R=3.69$ [2.46; 5.55]). Participants who received an addressed invitation (e-mail) without incentives were also more adherent to the intervention, but the difference was not statistically significant ( $\mathrm{aOR}=1.43[0.94 ; 2.18]$ ).

\section{Discussion}

This study showed that women, students with higher socioeconomic levels, and more motivated students were more adherent to an alcohol web-based intervention. In contrast, students who have 
been enrolled in the university for longer periods were less adherent. Hazardous use, binge drinking, and consuming a larger number of typical drinks were associated with higher adherence. The use of incentives (academic credits) was also associated with increased adherence. These results confirmed our hypothesis that students receiving incentives would be more adherent, as would participants with lower levels of alcohol use.

Our findings corroborate other studies, which indicated increased adherence rates among female participants and those with higher incomes (Lamers et al., 2012). Some authors showed that women show more health-related concerns and care (Levorato, Mello, Silva, \& Nunes, 2014). Given that the participants were invited to an alcohol web-based intervention, the increased adherence among women may reflect a more significant concern related to alcohol use among this population. In the Brazilian context, the use of information and communication technologies in residences occurs predominantly among the wealthiest groups of the population (CGI, 2017), since household internet access might facilitate the use of the website during the most convenient moments. This might also relate to the higher rates of adherence among college students from the Southern, Southeastern, and Midwestern regions of Brazil, where there is a higher proportion of residences with access to the internet (CGI, 2017).

Regarding the type of institution, students from public universities were also more adherent to the intervention. All participants were informed on the front page of the website that the intervention was associated with a scientific research. As the majority of Brazilian research is conducted by public institutions, these students may be more familiar with scientific studies, favoring their receptivity and perception of the need to collaborate, reflecting in more motivation to participate and adhere. In addition, our study showed that participants with higher AUDIT scores, reporting a greater number of typical drinks and the maximum number of drinks consumed on a single occasion, were more adherent. On the other hand, previous studies showed that heavy drinkers were less adherent, in particular during the follow-up assessments (Murray et al., 2013; Radtke et al., 2017). Overall, these findings suggest that attrition occurs in a complex fashion (Murray et al., 2013), in which factors other than drinking levels are also related to adherence. In this regard, our study showed that considering the risk group according to the AUDIT, only hazardous use of alcohol was significantly related to a higher adherence. Hazardous use is characterized by the use of alcohol but it does not necessarily present negative consequences. Our study also pointed out that the number of alcohol-related consequences did not predict adherence. In sum, the data suggests that higher alcohol use, but not the presence of consequences, is associated with higher adherence rates. Research suggests that consequences researchers traditionally viewed as unfavorable may, in fact, be taken as positive by students and might act as reinforcers of alcohol use (Mallett et al., 2013). Considered together, the data suggests that adherence might be associated with the intermediate characteristics of college students who drink alcohol but do not have many consequences or who have very low levels of alcohol consumption. This is following the finding that participants with hazardous alcohol use (not low risk, neither harmful or dependence) were also more adherent.

The use of monetary incentives is considered a form of enhancing adherence rates in web-based interventions (Khadjesari, Freemantle, Linke, Hunter, \& Murray, 2014; Laguilles et al., 2011). This was corroborated in a recent study showing that the effects of monetary incentives were particularly relevant among participants of web-based interventions (Neighbors et al., 2018). Our study advances to this literature showing that the use of non-monetary incentives (academic credits) also improved the participants' adherence. The type of incentive used in our study can be easily implemented in Brazil and it would help the dissemination of interventions without generating extra costs. Although web-based interventions for alcohol use among college students use incentives (Bedendo et al., 2018), there is a need for additional studies aiming to evaluate the effects of incentives on the efficacy of the intervention (Neighbors et al., 2018). This would help understand the real-world effects of the intervention among groups receiving different types of incentives (monetary or non-monetary). 
This study is one of the few that do not use monetary incentives in the literature, and it aimed to represent a real-world scenario where this web-based intervention would potentially be disseminated. Hence, adherence rates might be closer to those expected during the dissemination of the intervention. The adherence observed in this study was lower than in previous studies (Bertholet et al., 2015; Kypri et al., 2014), but this comparison is limited, given that such studies utilized financial incentives. A study not providing incentives showed that only $24.0 \%$ of participants were adherent after six months (Ekman et al., 2011), which is still superior to the rates observed in this current study (14.8\%). The differences might be related to methodological disparities between the studies, such as socioeconomic, educational, and cultural characteristics. The present study has a more diverse sample regarding educational and alcohol-consumption-related characteristics. Additionally, in our study, to have access to the intervention, participants needed to log in to the CIEE platform (requiring, therefore, that they have an account or create one), a step that might have led participants to give up accessing and could explain the lower adherence rates.

Despite the large sample size, this study is not representative of the population in Brazilian college students. However, the characteristics of our sample are similar to those observed in the Higher Education Census (Instituto Nacional de Estudos e Pesquisas Educacionais Anísio Teixeira, 2018) and in the First National Survey on the Use of Alcohol and other Drugs among College Students in Brazil (Andrade et al., 2010), highlighting the proportions of students in private institutions and the classification of alcohol use according to their risk zones. We considered an adapted version of the RAPI scale to assess the specific alcohol-related consequences. However, compared to the data extracted from the AUDIT questionnaire, the findings coadunate, in regard of consequences. Analyses regarding the use of incentives were performed with a relatively small number of participants, representing a subsample of the total number of college students recruited. This study was initially designed to evaluate the effectiveness of a web-based intervention, and future studies should evaluate the adherence rates in each recruitment strategy. On the other hand, this study was also designed to reflect a scenario of dissemination of this kind of intervention in the real world. Hence, adherence rates might be closer to those expected in a dissemination stage, favoring the generalization of our findings.

The increased adherence of participants recruited using non-financial incentives - academic credits -, suggests that this may be a useful strategy to improve students' enrollment rates without increasing intervention costs. The knowledge of the participants' characteristics accessing a web-based alcohol intervention may help the development of future interventions aiming at specific groups of students who were less adherent.

\section{Acknowledgments}

The Centro de Integração Empresa-Escola (Education-Business Integration Centre) for the development of the website and provision of e-mails for participant recruitment, and Associação Fundo de Incentivo à Pesquisa for technical and financial support.

\section{Contributions}

M. F. GONÇALVES performed the statistical analysis and drafted the first version of the manuscript. A. BEDENDO was responsible for the conceptualization of the study, data collection, and contributed to the statistical analysis and data interpretation. A. L. M. ANDRADE contributed to the data collection and edited the manuscript. A. R. NOTO contributed to the conceptualization and data interpretation. All authors reviewed and approved the final version of the manuscript. 


\section{References}

Andrade, A. G., Duarte, P., \& Oliveira, L. G. (2010). I levantamento nacional sobre o uso de álcool, tabaco e outras drogas entre universitários das 27 capitais brasileiras. Brasília: Secretaria Nacional de Políticas sobre Drogas. Recuperado de https://cetadobserva.ufba.br/sites/cetadobserva.ufba.br/files/634.pdf

Andrade, A. L. M., Lacerda, R. B., Gomide, H. P., Ronzani, T. M., Sartes, L. M. A., Martins, L. F., ... Sousa-Formigoni, M. L. O. (2016). Web-based self-help intervention reduces alcohol consumption in both heavy-drinking and dependent alcohol users: a pilot study. Addictive Behaviors, 63, 63-71. https://doi.org/10.1016/j.addbeh.2016.06.027

Beatty, L., \& Binnion, C. (2016). A systematic review of predictors of, and reasons for, adherence to online psychological interventions. International Journal of Behavioral Medicine, 23(6), 776-794. https://doi.org/10.1007/s12529-016-9556-9

Bedendo, A., Andrade, A. L. M., Opaleye, E. S., \& Noto, A. R. (2017). Binge drinking: a pattern associated with a risk of problems of alcohol use among university students. Revista Latino-Americana de Enfermagem, 25, e2925. https:// doi.org/10.1590/1518-8345.1891.2925

Bedendo, A., Andrade, A. L. M., \& Noto, A. R. (2018). Internet-based alcohol interventions for college students: systematic review. Pan American Journal of Public Health, 42, e54. https://doi.org/10.26633/RPSP.2018.54

Bedendo, A., Ferri, C. P., Souza, A. A. L., Andrade, A. L. M., \& Noto, A. R. (2019a). Pragmatic randomized controlled trial of a web-based intervention for alcohol use among Brazilian college students: motivation as a moderating effect. Drug and Alcohol Dependence, 199, 92-100. https://doi.org/10.1016/j.drugalcdep.2019.02.021

Bedendo, A., McCambridge, J., Gaume, J., Souza, A. A. L., Souza-Formigoni, M. L. O., \& Noto, A. R. (2019b). Components evaluation of a web-based personalised normative feedback intervention for alcohol use among college students: a pragmatic randomised controlled trial with a dismantling design. Addiction, 115(6), 1063-1074. https://doi. org/10.1111/add.14923

Bedendo, A., \& Noto, A. R. (2016). Studying an unreal world: incentives on internet-based interventions for alcohol use. Addiction, 111(2), 373-374. https://doi.org/10.1111/add.13171

Bertholet, N., Cunningham, J. A., Faouzi, M., Gaume, J., Gmel, G., Burnand, B., \& Daeppen, J. B. (2015). Internet-based brief intervention for young men with unhealthy alcohol use: a randomized controlled trial in a general population sample. Addiction, 110(11), 1735-1743. https://doi.org/10.1111/add.13051

Brouwer, W., Kroeze, W., Crutzen, R., Nooijer, J., Vries, N. K., Brug, J., \& Oenema, A. (2011). Which intervention characteristics are related to more exposure to internet-delivered healthy lifestyle promotion interventions? A systematic review. Journal of Medical Internet Research, 13(1), e2. https://doi.org/10.2196/jmir.1639

Comitê Gestor da Internet no Brasil. (2017). Pesquisa sobre o uso das tecnologias de informação e comunicação nos domicilios brasileiros: T/C domicílios 2016. São Paulo: Autor. Recuperado de https://cetic.br/media/docs/publicacoes/2/ TIC_DOM_2016_LivroEletronico.pdf

Ekman, D. S., Andersson, A., Nilsen, P., Stahlbrandt, H., Johansson, A. L., \& Bendtsen, P. (2011). Electronic screening and brief intervention for risky drinking in Swedish university students: a randomized controlled trial. Addictive Behaviors, 36(6), 654-659. https://doi.org/10.1016/j.addbeh.2011.01.015

Escoffery, C., Miner, K. R., Adame, D. D., Butler, S., McCormick, L., \& Mendell, E. (2005). Internet use for health information among college students. Journal of American College Health, 53(4), 183-188. https://doi.org/10.2196/jmir.7.1.e11

Eysenbach, G. (2005). The law of attrition. Journal of Medical Internet Research, 7(1), e11. https://doi.org/10.2196/ jmir.7.1.e11

Geraghty, A. W., Torres, L. D., Leykin, Y., Pérez-Stable, E. J., \& Muñoz, R. F. (2013). Understanding attrition from international internet health interventions: a step towards global eHealth. Health Promotion International, 28(3), 442-452. https:// doi.org/10.1093/heapro/das029

Geraghty, A. W., Wood, A. M., \& Hyland, M. E. (2010). Attrition from self-directed interventions: investigating the relationship between psychological predictors, intervention content and dropout from a body dissatisfaction intervention. Social Science \& Medicine, 71(1), 30-37. https://doi.org/10.1016/j.socscimed.2010.03.007

Göritz, A. S. (2006). Incentives in web studies: methodological Issues and a review. International Journal of Internet Science, 1(1), 58-70. Retrieved from https://www.ijis.net/ijis1_1/ijis1_1_goeritz_pre.html

Instituto Nacional de Estudos e Pesquisas Educacionais Anísio Teixeira. (2018). Sinopse estatística da Educação Superior 2017. Brasília: Autor. Recuperado de http://inep.gov.br/sinopses-estatisticas-da-educacao-superior

Khadjesari, Z., Freemantle, N., Linke, S., Hunter, R., \& Murray, E. (2014). Health on the web: randomised controlled trial of online screening and brief alcohol intervention delivered in a workplace setting. Plos One, 9(11), e112553. https:// doi.org/10.1371/journal.pone.0112553 
Kypri, K., Vater, T., Bowe, S. J., Saunders, J. B., Cunningham, J. A., Horton, N. J., \& McCambridge, J. (2014). Web-based alcohol screening and brief intervention for university students: a randomized trial. Jama, 311(12), 1218-1224. https:// doi.org/10.1001/jama.2014.2138

Laguilles, J. S., Williams, E. A., \& Saunders, D. B. (2011). Can lottery incentives boost web survey response rates? Findings from four experiments. Research in Higher Education, 52(5), 537-553. https://doi.org/10.1007/s11162-010-9203-2

Lamers, F., Hoogendoorn, A. W., Smit, J. H., van Dyck, R., Zitman, F. G., Nolen, W. A., \& Penninx, B. W. (2012). Sociodemographic and psychiatric determinants of attrition in the Netherlands Study of Depression and Anxiety (NESDA). Comprehensive Psychiatry, 53(1), 63-70. https://doi.org/10.1016/j.comppsych.2011.01.011

Levorato, C. D., Mello, L. M., Silva, A. S., \& Nunes, A. A. (2014). Fatores associados à procura por serviços de saúde numa perspectiva relacional de gênero. Ciência \& Saúde Coletiva, 19(4). https://doi.org/10.1590/1413-81 232014194.01242013

Mallett, K. A., Varvil-Weld, L., Borsari, B., Read, J. P., Neighbors, C., \& White, H. R. (2013). An update of research examining college student alcohol-related consequences: new perspectives and implications for interventions. Alcoholism, Clinical and Experimental Research, 37(5), 709-16. https://doi.org/10.1111/acer.12031

Murray, E., White, I. R., Varagunam, M., Godfrey, C., Khadjesari, Z., \& McCambridge, J. (2013). Attrition revisited: adherence and retention in a web-based alcohol trial. Journal of Medical Internet Research, 15(8), e162. https://doi. org/10.2196/jmir.2336

Neighbors, C., Rodriguez, L. M., Garey, L., \& Tomkins, M. M. (2018). Testing a motivational model of delivery modality and incentives on participation in a brief alcohol intervention. Addictive Behaviors, 84, 131-138. https://doi.org/10.1016/j. addbeh.2018.03.030

Pedersen, D. H., Mansourvar, M., Sorts, C., \& Schmidt, T. (2019). Predicting dropouts from an electronic health platform for lifestyle interventions: analysis of methods and predictors. Journal of Medical Internet Research, $21(9)$, e13617. https://doi.org/10.2196/jmir.13617

Poppe, L., van der Mispel, C., Bourdeaudhuij, I., Verloigne, M., Shadid, S., \& Crombez, G. (2017). Users' thoughts and opinions about a self-regulation-based eHealth intervention targeting physical activity and the intake of fruit and vegetables: a qualitative study. Plos One, 12(12), e0190020. https://doi.org/10.1371/journal.pone.0190020

Radtke, T., Ostergaard, M., Cooke, R., \& Scholz, U. (2017). Web-based alcohol intervention: study of systematic attrition of heavy drinkers. Journal of Medical Internet Research, 19(6), e217. https://doi.org/10.2196/jmir.6780

Schaub, M. P., Tiburcio, M., Martinez, N., Ambekar, A., Balhara, Y. P. S., Wenger, A., ... Souza-Formigoni, M. L. O. (2018). Alcohol e-Help: study protocol for a web-based self-help program to reduce alcohol use in adults with drinking patterns considered harmful, hazardous or suggestive of dependence in middle-income countries. Addiction, 113(2), 346-352. https://doi.org/10.1111/add.14034

Schulenberg, J. E., Johnston, L. D., O’Malley, P. M., Bachman, J. G., Miech, R. A., \& Patrick, M. E. (2018). Monitoring the future: national survey results on drug use, 1975-2017. Ann Arbor: Institute for Social Research. Retrieved from http://monitoringthefuture.org/pubs.html\#monographs

Schulz, D. N., Candel, M. J., Kremers, S. P., Reinwand, D. A., Jander, A., \& Vries, H. (2013). Effects of a Web-based tailored intervention to reduce alcohol consumption in adults: randomized controlled trial. Journal of Medical Internet Research, 15(9), e206. https://doi.org/10.2196/jmir.2568

Silva, E. C., \& Tucci, A. M. (2015). Intervenção breve para redução do consumo de álcool e suas consequências em estudantes universitários brasileiros. Psicologia: Reflexão e Crítica, 28(4), 728-736. https://doi.org/10.1590/1678-7 153.201528410

Sundstrom, C., Blankers, M., \& Khadjesari, Z. (2017). Computer-based interventions for problematic alcohol use: a review of systematic reviews. International Journal of Behavioral Medicine, 24(5), 646-658. https://doi.org/10.1007/ s12529-016-9601-8

van der Mispel, C., Poppe, L., Crombez, G., Verloigne, M., \& Bourdeaudhuij, I. (2017). A Self-regulation-based eHealth intervention to promote a healthy lifestyle: investigating user and website characteristics related to attrition. Journal of Medical Internet Research, 19(7), e241. https://doi.org/10.2196/jmir.7277

World Health Organization. (2015). E-Health. Geneva: Author. Retrieved from https://www.who.int/ehealth/en/

World Health Organization. (2018). Global status report on alcohol and health 2018. Geneva: Author. Retrieved from https://www.who.int/substance_abuse/publications/global_alcohol_report/en/

Received: September 23, 2019

Final version: May, 8, 2020

12

Approved: June 11, 2020 